\title{
GENOTYPE $\times$ ENVIRONMENT INTERACTION AND STABILITY ANALYSIS FOR SOME ECONOMIC CHARACTERS IN SNAP BEAN
}

Heba Z. Ibrahem ${ }^{1^{*}}$, Ragab ${ }^{2}$ M.E., Noura M. Taha ${ }^{2}$ and Entsar M.E. Abo-Hamda ${ }^{1}$

1- Horticulture Research Institute, Agric. Research Center, Giza, Egypt.

2- Horticulture Dept., Fac. of Agric., Ain Shams Univ., P.O. Box 68, Hadayek Shobra11241, Cairo, Egypt

*Corresponding author: hebazain83@gamil.com

\section{ABSTRACT}

Twenty-one new promising lines in addition to four standard cultivars of snap bean (Phaseolus vulgaris L.) were evaluated under eight environmental conditions (four sowing dates in two seasons of 2015/2016 and 2016/2017). A randomized complete block design (RCBD) with three replicates was used for each sowing date at Barrage Horticulture Research Station (BHRS), Qalubia Governorate, Horticulture Research Institute (HRI), Agricultural Research Center (ARC), Egypt. Data were recorded for some traits i.e., number of days to flowering, pod length, pod diameter, fiber content, total green yield and rust disease severity. The results showed that the linear response of environments was highly significant for all studied characters, indicating the differences between environmental conditions and their considerable influence on these traits. Mean squares of genotypes (G) were highly significant for all studied traits, suggesting the presence of wide range of differences between studied genotypes concerning all investigated traits. Mean squares of the other main sources of variation, i.e., years $(Y)$ and sowing dates (D) were also highly significant for all traits except year for total green yield/feddan trait. The mean square due to environment + (Genotypes $\times$ Environment) was significant for all studied traits, indicating that there was a considerable interaction of genotypes with environmental condition in different eight environments. Significance of Genotypes $\times$ Environment (linear), reveals that genotypes differed in their considerably across different environments. The linear response of environments was highly significant for total green yield trait, indicating that genotypes differed in their regression on the environmental index. The results of stability analysis conclude that the six new lines $G_{1}, G_{2}, G_{3}, G_{7}, G_{10}$ and $G_{18}$, were the most stable genotypes, which gave the maximum total green yield overall the eight studied environments and were adapted to environments for total green yield. It is evident that these genotypes could be used as stress tolerant genotypes under stressed environments.

Keywords: Snap bean, Stability, Genotype $\times$ Environment

\section{INTRODUCTION}

Snap bean (Phaseolus vulgaris L.) is an important vegetable legume crop which belongs to family of Leguminosae. In Egypt, this crop is grown for both export and local consumption. Also, as a legume crop, it complies well into cereal rotations with providing nitrogen to the soil, need short period and it can reduce the intensity of diseases in non-legume crops if it is managed properly. Snap bean is a well-established vegetable of Egyptian agriculture and is regarded as the main cash crop of the farmers in many areas of Egypt with an estimated production area of 50946 feddans yielded 193291 tons with an average of 3.794 tons per feddan.

Plant breeders look for greater variability in crop plants for evolving lines which give maximum yield over the environments and show consistent performance. It is imperative that most adaptable cultivars should be developed to improve the productivity of snap bean in view of climate change. Significant effect was found between varieties on number of days to flowering of green bean 
(Seyum, 2014). Non-significant differences were determined among cultivars for pods fiber content (Getachew et al 2015). Getachew et al (2014a), Pereira et al (2014), Seyum (2014), Getachew et al (2015), Swegarden et al (2016) and Tadesse et al (2017) found that genotype generally exhibited significant positive influence on yield trait. Also, Mounir et al (2015) cultivated 2 snap bean cultivars (Xera and Bronco) in different sowing dates (Oct. $1^{\text {st }}, 8^{\text {th }}$ and $15^{\text {th }}$ ) in Egypt and the results indicated the effect of genotypes on total yield character. On the other side, Getachew et al (2014b) found that different genotypes exhibited nonsignificant influence on yield trait. Pod length was significantly influenced by different cultivars (Yoldas and Esiyok, 2007 and Getachew et al 2014b), however, Getachew et al (2014a) found that this trait was non-significantly influenced by different cultivars. For pod diameter trait of green bean, significant effect was found between cultivars (Getachew et al 2014a, Getachew et al 2014b and Mounir et al 2015).

Sowing date, environment and cultural practices influenced yield and its characteristics. Among the various agronomic practices, optimum sowing date and best cultivar are of primary importance for potential yield. Number of days to $50 \%$ flowering trait showed highly significant differences for sowing dates (Seyum, 2014). Total yield trait showed significant differences for sowing dates (Yoldas and Esiyok, 2007, Getachew et al 2014a, Elhag and Hussein, 2014, Seyum, 2014 and Getachew et al 2015). However, Esmaeilzadeh and Aminpanah (2015) indicated that total pod yield trait showed non-significant differences for sowing dates. Mounir et al (2015) cultivated two snap bean cultivars (Xera and Bronco) in different sowing dates (Oct. $1^{\text {st }}, 8^{\text {th }}$ and $15^{\text {th }}$ ) in Egypt and found that sowing seeds on Oct. $8^{\text {th }}$ resulted in increasing in total yields compared to other sowing dates. They also found that delaying sowing date from Oct. $1^{\text {st }}$ to Oct. $8^{\text {th }}$ significantly reduced pod diameter. Significant differences for sowing dates were obtained for pod length trait (Yoldas and Esiyok, 2007, Getachew et al 2014a), however, Esmaeilzadeh and Aminpanah (2015) indicated that pod length trait showed non-significant differences for sowing dates. Highly significant differences for sowing dates were showed for pods fiber content trait (Getachew et al 2015). Rust incidence trait showed highly significant differences for sowing dates (Getachew et al 2015).

Few cultivars have been recommended in Egypt over the last two decades. Release of a snap bean cultivar in any country occurs after its evaluation in uniform cultivar performance tests over different environments. An understanding of responses of recommended cultivars to environment assist breeders in the use of materials in breeding programs and in recommending cultivars for specific areas within bean producing region.

The general approach for studying the genotype by environment $(G \times E)$ interaction is analysis of variance and estimates of variance components (Comstock and Moll 1963). The variances most useful to plant breeders are interactions involving cultivar and environment. However, the analysis of variance technique does not indicate the response of each individual genotype to the environment. Significant interaction effects were found between varieties and sowing date on number of days to flowering of green bean (Seyum, 2014; Hussein and Abd El-Hady, 2015 on cowpea). Significant interaction effects was found between varieties and sowing date on fibers content trait of green bean (Getachew et al 2015). Khalifa et al (2013), Pereira et al (2014), Mounir et al (2015), Swegarden et al (2016) and Tadesse et al (2017) indicated the effects of interaction between genotypes and sowing dates on total yield character. However, Non-significant interaction effect was found between varieties and sowing date on total pod yield of green bean (Getachew et al 2014a, Seyum, 2014 and Getachew et al 2015). Pod length and pod diameter traits were significantly influenced by the interaction effect of variety and sowing date (Getachew et al 2014a, Getachew et al 2014b, and Mounir et al 2015). Getachew et al (2015) and Pereira et al (2014) found that the genotype $\times$ environment interaction differed significantly for tolerant rust disease trait.

A linear regression technique has been developed to estimate the stability of cultivar performance over environments (Finlay and Wilkinson 1963). Eberhart and Russell (1966) defined a desired type as being a cultivar with a high mean yield, unit regression coefficient $\left(b_{i}=1.0\right)$ and deviation from regression as small as possible $\left(S^{2}{ }_{d}=\right.$ $0)$. Tadesse et al (2017) evaluated 16 different common bean genotypes and found that stable cultivar wouldn't necessarily give the highest seed yield. However, Carbonell et al (2004) indicated that the most stable cultivars were always associated to the highest yield. Pereira et al (2014) evaluated 12 different genotypes of common bean under different environments and found that CNFB 16211 line presented high stability and adaptability and therefore this line may be a new cultivar. Fur- 

economic characters in snap bean

ther lines BRS Radiante, Poroto Alúbia and Alúbia Argentina exhibited the highest indices of stability/adaptability in unfavorable environments. Swegarden et al (2016) cultivated 20 dry bean cultivars in different environments and the results indicated that only three genotypes were stable for total yield character.

Hence, the present study aimed to investigate the performance of twenty one new promising lines and four check (control) cultivars snap bean genotypes and their phenotypic stability over variable environmental conditions.

\section{MATERIALS AND METHODS}

This study was conducted during the period from 2015 to 2017 at Barrage Horticulture Research Station (BHRS), Qalubia Governorate, Horticulture Research Institute (HRI), Agricultural Research Center (ARC), Egypt to evaluate some snap bean (Phaseolus vulgaris L.) genotypes for rust [Uromyces appendiculatus (Pers.) Unger] resistance, pod quality and productivity under various sowing dates. Also, the study aimed to study the interaction between genotypes and environmental conditions and its effect on the genetic stability of these snap bean genotypes and analyze its stability under different planting dates and identify the best genotype during different planting dates.

Twenty one new promising lines and four check cultivars of snap bean were evaluated under eight environments. Advanced lines were derived from the crosses of Bronco x Giza 6, Concessa x Paulista and Concessa $\times$ Samantha through previous breeding programs of snap bean, Horticulture Research Institute, ARC, Egypt (Khereba et al 2000, Hamed et al 2012 and Hamed and Muhanna, 2017). Also, four check cultivars namely Bronco, Paulista, Samantha and Xera were used as shown in Table (1). All genotypes were sown during the seasons of 2015/2016 and 2016/2017 in four sowing dates for each year (two sowing dates for fall season and two sowing dates for summer season). Seeds were sown on first week of September $\left(D_{1}\right)$ and first week of October $\left(D_{2}\right)$ for the two autumn seasons and mid of February $\left(D_{3}\right)$ and mid of March $\left(D_{4}\right)$ for the two summer seasons. A randomized complete block design (RCBD) with three replicates was used for each sowing date. In the eight sowing dates, each plot consisted of three rows, each row was $0.70 \mathrm{~m}$ wide and $3.0 \mathrm{~m}$ long and the plants were spaced at $5-7 \mathrm{~cm}$ apart. The recommended agricultural practices such as irrigation and chemical fertilization were done but without using rust control fungicides.

Table 1. Pedigree of the studied snap bean genotypes

\begin{tabular}{|c|c|c|c|c|c|c|c|}
\hline No. & Genotypes & Erom & Origin & No. & Genotypes & Erom & Origin \\
\hline $\mathrm{G}_{1}$ & FA 2-13 & Concessa $\times$ Samantha & Egypt & $\mathbf{G}_{14}$ & FA 1-12 & Concessa x Paulista & Egypt \\
\hline $\mathrm{G}_{2}$ & FA 2-6 & Concessa $\times$ Samantha & Egypt & $\mathbf{G}_{15}$ & FA 2-9 & Concessa $\times$ Samantha & Egypt \\
\hline $\mathrm{G}_{3}$ & FA 2-14 & Concessa $\times$ Samantha & Egypt & $\mathbf{G}_{16}$ & FA 2-33 & Concessa $x$ Samantha & Egypt \\
\hline $\mathbf{G}_{4}$ & FA 2-15 & Concessa $\times$ Samantha & Egypt & $\mathbf{G}_{17}$ & FA 2-26 & Concessa $\times$ Samantha & Egypt \\
\hline $\mathrm{G}_{5}$ & FA $1-16$ & Concessa $x$ Paulista & Egypt & $\mathbf{G}_{18}$ & FA 2-1 & Concessa $\times$ Samantha & Egypt \\
\hline $\mathrm{G}_{6}$ & FA 2-6 & Concessa $\times$ Samantha & Egypt & $\mathbf{G}_{19}$ & FA 2-23 & Concessa $\times$ Samantha & Egypt \\
\hline $\mathrm{G}_{7}$ & FA 2-7 & Concessa $\times$ Samantha & Egypt & $\mathbf{G}_{20}$ & FA 2-31 & Concessa $\times$ Samantha & Egypt \\
\hline $\mathrm{G}_{8}$ & FA 2-22 & Concessa $\times$ Samantha & Egypt & $\mathbf{G}_{21}$ & FA 2-2 & Concessa $\times$ Samantha & Egypt \\
\hline $\mathbf{G}_{9}$ & FA 2-17 & Concessa $\times$ Samantha & Egypt & & Bronco & Check & USA \\
\hline $\mathrm{G}_{10}$ & FA 1-2 & Concessa $\times$ Paulista & Egypt & & Paulista & Check & Netherland \\
\hline $\mathrm{G}_{11}$ & FA 418 & Bronco x Giza6 & Egypt & & Samantha & Check & USA \\
\hline $\mathrm{G}_{12}$ & FA 435 & Bronco x Giza6 & Egypt & & Xera & Check & USA \\
\hline $\mathrm{G}_{13}$ & FA 2-3 & Concessa $\times$ Samantha & Egypt & & & & \\
\hline
\end{tabular}

Monthly average degree of maximum and minimum temperatures $\left({ }^{\circ} \mathrm{C}\right)$ and relative humidity (\%) at the experimental site during the period of study were kindly provided by the Central Laboratory for
Agricultural Climate (CLAC), Ministry of Agriculture and Land Reclamation, Egypt as shown in Table (2). 
Table 2. Monthly air temperature and relative humidity in Qalubia region during the period of the experiment

\begin{tabular}{|c|c|c|c|c|c|c|c|c|c|}
\hline \multirow{3}{*}{ Months } & \multicolumn{3}{|c|}{$2015 / 2016$ season } & \multicolumn{3}{|c|}{$2016 / 2017$ season } & \multicolumn{3}{|c|}{$2017 / 2018$ season } \\
\hline & \multicolumn{2}{|c|}{$\begin{array}{c}\text { Temperature } \\
\left({ }^{\circ} \mathrm{C}\right)\end{array}$} & \multirow[b]{2}{*}{\begin{tabular}{|c} 
Relative \\
humidity \\
$(\%)$
\end{tabular}} & \multicolumn{2}{|c|}{$\begin{array}{c}\text { Temperature } \\
\left({ }^{\circ} \mathrm{C}\right)\end{array}$} & \multirow{2}{*}{$\begin{array}{c}\text { Temperature } \\
\left({ }^{\circ} \mathrm{C}\right) \\
\text { Relative } \\
\text { humidity } \\
(\%)\end{array}$} & & & \multirow{2}{*}{\begin{tabular}{|c}
$\begin{array}{c}\text { Temperature } \\
\left({ }^{\circ} \mathrm{C}\right)\end{array}$ \\
Relative \\
humidity \\
$(\%)$
\end{tabular}} \\
\hline & $\max$ & $\min$ & & $\max$ & $\min$ & & $\max$ & $\min$ & \\
\hline January & & & & & & & 24.8 & 11.1 & 63.2 \\
\hline February & & & & 22.9 & 11.1 & 67.1 & 28.1 & 10.1 & 63.5 \\
\hline March & & & & 33.3 & 11.3 & 50.7 & 33.5 & 11.5 & 55.9 \\
\hline April & & & & 40.7 & 13.3 & 47.0 & 41.4 & 12.9 & 51.0 \\
\hline May & & & & 46.3 & 16.6 & 44.0 & 41.9 & 17.4 & 45.7 \\
\hline June & & & & 44.0 & 20.8 & 47.5 & 43.9 & 19.6 & 49.0 \\
\hline July & & & & & & & 42.6 & 23.2 & 55.5 \\
\hline September & 39.3 & 22.2 & 53.7 & 42.0 & 20.8 & 55.6 & & & \\
\hline October & 36.9 & 13.9 & 60.1 & 36.5 & 17.2 & 62.4 & & & \\
\hline November & 30.2 & 13.5 & 72.2 & 30.5 & 12.5 & 60.4 & & & \\
\hline December & 23.5 & 11.0 & 74.2 & 23.3 & 10.5 & 65.7 & & & \\
\hline
\end{tabular}

Data were recorded on the traits of number of days to flowering, pod length, pod diameter, pod fiber content, total green yieldand rust disease severity. Number of days to flowering trait was measured as the number of days from sowing until reaching to flowering of $50 \%$ of plants number of each plot. Pod length $(\mathrm{cm})$ trait was measured as the mean length of random 25 pods per plot harvested in the suitable consuming time. Pod diameter $(\mathrm{mm})$ trait was measured as the distance from dorsal to ventral suture at the largest section of pod and it was measured as the mean diameter of random 25 pods per plot harvested in the suitable consuming time. Fiber content $(\mathrm{g} / 100 \mathrm{~g}$ fresh pod weight) trait was determined according to the methods described in A.O.A.C. (1990). Total green yield (ton/feddan) trait was calculated as the weight of all pods harvested throughout all season. Disease severity assessment of rust was determined based on detection of the first visible symptoms in each sowing date. Infection types of bean rust were evaluated after the fungus had fully established under the natural field conditions by using the 1-6 scale described by Stavely et al (1989). Infection grading 1, 2 and 3 were considered incompatible (resistant) and 4, 5 and 6 were considered compatible (susceptible) as shown in Table (3) and Fig. (1). Thirty leaves/plot were taken to estimate disease severity of each particular genotype representing the amount of area diseased. The percentage of infection was determined on the lower surface of leaf. The percentage of infection for each particular genotype was calculated by using the following formula:

$$
\text { D.I. }=\frac{\text { Sum of }(n \times v)}{6 N} \times 100
$$

Where: D.I. $=$ Disease index, $n=$ Number of leaflets in each category, $v=$ Numerical value of each category and $\mathrm{N}=$ Total number of leaflets in sample. 

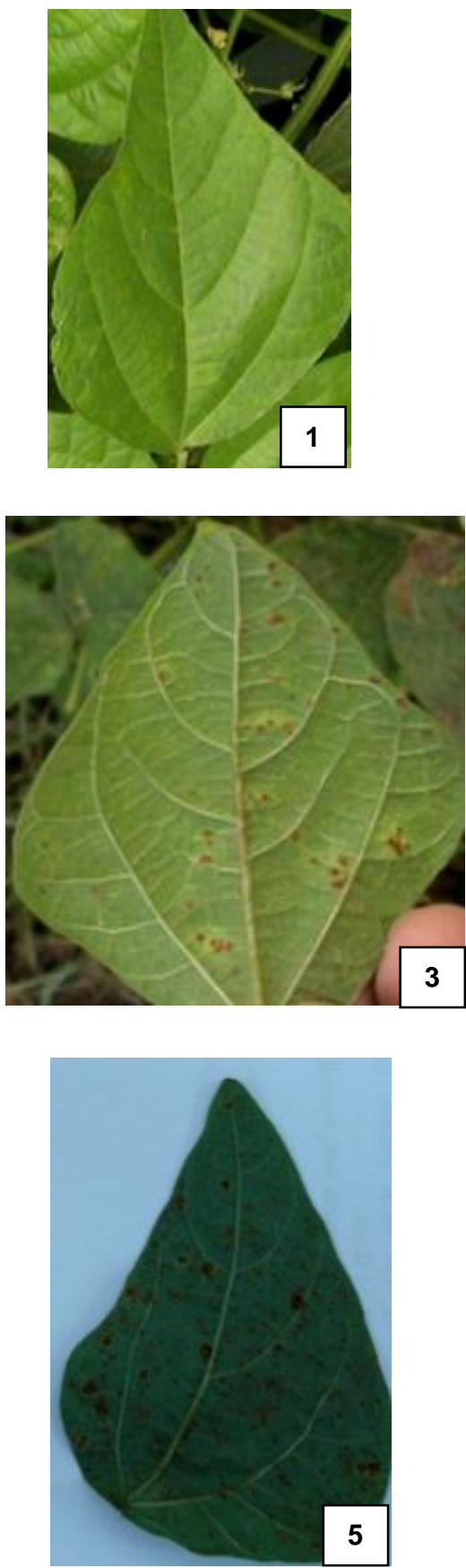
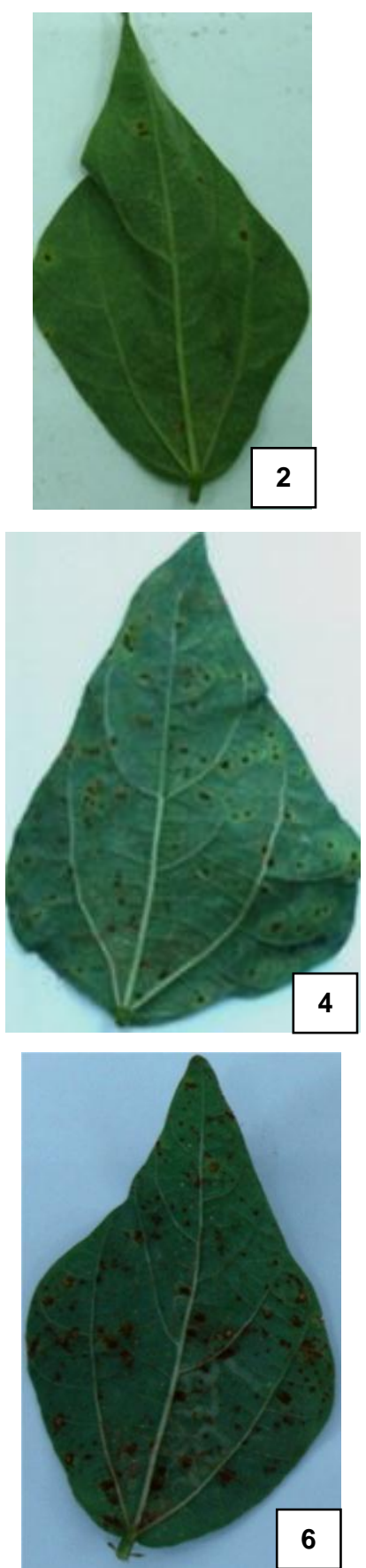

Fig. 1. Disease scale used for evaluation of snap bean genotypes for rust reaction ( $1=$ immune, 2 $=$ highly resistant, 3 = resistant, 4 = susceptible, $5=$ moderately susceptible and $6=$ highly susceptible). 
Table 3. Disease scale used for evaluation of snap bean genotypes for rust reaction

\begin{tabular}{|c|l|l|c|}
\hline Rating score & \multicolumn{1}{|c|}{ Description } & \multicolumn{2}{c|}{ Reaction to disease } \\
\hline 1 & No rust symptoms & Immune & Incompatible \\
2 & Necrotic spots without sporulation & Highly resistant (hypersensitive) & $"$ \\
3 & Pustules $<300 \mu \mathrm{m}$ in diameter & Resistant & $"$ \\
4 & Pustules $300-500 \mu \mathrm{m}$ in diameter & Susceptible & Compatible \\
5 & Pustules $500-800 \mu \mathrm{m}$ in diameter & Moderately susceptible & $"$ \\
6 & Pustules $>800 \mu \mathrm{m}$ in diameter & Highly susceptible & $"$ \\
\hline
\end{tabular}

Combined analysis of variance was performed across the eight environments (two years and four sowing dates) to detect the genotype by environment interaction effects as described by Snedecor and Cochran (1967). The data of each trait were statistically analyzed as shown by Eberhart and Russell (1966). Disease severity data were transformed before statistical analysis using angular transformation method.

\section{RESULTS AND DISCUSSION}

\section{1- Analysis of variance components}

Mean squares of analysis of variance over two years, and four sowing dates for the investigated traits of snap bean genotypes are given in Table (4). Mean squares of genotypes (G) were highly significant for all studied traits, suggesting the presence of wide range of differences between studied genotypes concerning all investigated traits. Mean squares of the other main sources of variation, i.e., years $(\mathrm{Y})$ and sowing dates (D) were also highly significant for all traits except year for total green yield/feddan trait.

Concerning the interaction, all order interactions among different factors in this study were highly significant for all studied traits, indicating that environmental factors have important role in the expression of these traits and that suggesting the importance of genotypes under different sowing dates to identify the best genotypes for a particular or several sowing dates.

Some studies found significant interactions between snap bean genotypes and sowing dates factors for one or more of snap bean traits, viz., Khalifa et al (2013), Getachew et al (2014a), Getachew et al (2014b), Pereira et al (2014), Seyum (2014), Getachew et al (2015), Hussein and Abd El-Hady (2015), Mounir et al (2015), Swegarden et al (2016) and Tadesse et al (2017).

Table 4. Mean squares of combined analysis of variance for twenty one and four chick (control) snap bean genotypes $(G)$ over four sowing dates $(D)$ and two years $(Y)$ for the studied traits in 2015/2016 and 2016/2017 growing seasons

\begin{tabular}{|c|c|c|c|c|c|c|c|}
\hline $\begin{array}{c}\text { Source } \\
\text { of variation }\end{array}$ & d.f. & $\begin{array}{c}\text { No. days to } \\
\text { flowing }\end{array}$ & $\begin{array}{c}\text { Pod } \\
\text { length }\end{array}$ & Pod diameter & $\begin{array}{c}\text { Pods } \\
\text { fiber } \\
\text { content }\end{array}$ & $\begin{array}{c}\text { Total green } \\
\text { yield }\end{array}$ & $\begin{array}{c}\text { Rust } \\
\text { disease } \\
\text { severity }\end{array}$ \\
\hline Y & 1 & $15.00^{* *}$ & $12.95^{* *}$ & $2.38^{* *}$ & $77.62^{* *}$ & 0.01 & $0.10^{* *}$ \\
D & 3 & $1660.00^{* *}$ & $12.44^{* *}$ & $2.91^{* *}$ & $215.64^{* *}$ & $64.08^{* *}$ & $0.53^{* *}$ \\
DY & 3 & $50.72^{* *}$ & $10.41^{* *}$ & $1.86^{* *}$ & $99.82^{* *}$ & $0.99^{* *}$ & $0.17^{* *}$ \\
RDY & 15 & $0.543^{*}$ & 0.005 & 0.011 & 2.951 & 0.006 & 0.008 \\
G & 24 & $135.16^{* *}$ & $31.13^{* *}$ & $9.03^{* *}$ & $2130.38^{* *}$ & $4.60^{* *}$ & $0.28^{* *}$ \\
GY & 24 & $2.33^{* *}$ & $0.54^{* *}$ & $0.14^{* *}$ & $99.14^{* *}$ & $0.29^{* *}$ & $0.16^{* *}$ \\
GD & 72 & $14.63^{* *}$ & $0.99^{* *}$ & $0.40^{* *}$ & $73.37^{* *}$ & $0.87^{* *}$ & $0.10^{* *}$ \\
GDY & 72 & $2.50^{* *}$ & $0.92^{* *}$ & $0.18^{* *}$ & $38.88^{* *}$ & $0.19^{* *}$ & $0.10^{* *}$ \\
RGDY & 381 & 0.30 & 0.09 & 0.03 & 4.62 & 0.03 & 0.02 \\
\hline Total & 599 & & & & & & \\
\hline
\end{tabular}




\section{Genotype $\times$ environment interaction and stability analysis for some}

economic characters in snap bean

\section{2- Performance of genotypes under different environments}

The mean performance for some economic characters of twenty five snap bean genotypes under 8 environments is given in Tables (5-10). Data showed that all studied traits were significantly affected by years, sowing dates, genotypes and their interactions. These results indicated that wide diversity existed among all snap bean genotypes concerning their performance as affected by various investigated factors.

With respect to the effect of years, it was observed that a significant increase was found in the second year than in the first one for all studied characters except for pods fiber content traits whereas data revealed that non significant difference were obtained between first and second years, also, rust disease severity trait whereas data revealed that first year was significantly higher than the second one. Results showed also that the second year yielded the highest mean values for total green yield/feddan (4.16 tons) exceeding by about $1.70 \%$ than the first year (4.09 tons). Data revealed that the first year was significantly highest in rust disease severity $(9.07 \%)$ than the second year $(7.97 \%)$. The differences in the results in years may be explained by the differences in climatic conditions at the two years (Table 2).

Regarding to the sowing dates, the obtained results indicated that the two sowing dates in the autumn (First week of September and October) were earlier than the two sowing dates in the summer (Mid of February and March). Earliness in the sowing date in the autumn might be due to high temperature degrees during the germination period in September and October comparing with that in February and March which caused faster germination and vegetative growth in the autumn than in the summer dates for most genotypes. Results indicated that delaying of sowing date in both autumn and summer seasons gave a significant increase of pod length and decreased pod diameter trait. High temperature during early autumn and late summer may be the reason for the rapid pod developing. These results reflect the wide differences in climatic conditions prevailing during early and late planting. For pod fiber content trait, September as a sowing date in the two studied years recorded the lowest fiber content and gave values of 1.33 and $1.44 \mathrm{~g} / 100 \mathrm{~g}$ fresh pod weight in the first and second years, respectively. Results indicated also that total green yield trait was signifi- cantly increased in the case of late fall date and early summer sowing dates, which recorded values of 4.48 and 4.52 tons in the first year and 4.40 and 4.59 tons in the second year, respectively, comparing with early fall date and late summer sowing dates which recorded values of 3.64 and 3.71 tons in the first year and 3.66 and 3.99 tons in the second year, respectively. Rust disease severity character was significantly affected by time of sowing. In the two years, favorable climatic conditions in late fall and early summer sowing dates lead to maximum rust disease severity which gave a mean values of 11.37 and $11.73 \%$ of rust disease severity which gave a mean value of 11.37 and $11.73 \%$ rust disease severity for late fall sowing dates and 12.27 and $8.73 \%$ for early summer sowing dates in the two years, respectively. Similar results were recorded by Yoldas and Esiyok (2007), Elhag and Hussein (2014), Getachew et al (2014a and b), Seyum (2014), Getachew et al (2015) and Mounir et al (2015) who indicated that this trait showed significant differences for sowing dates. However, Esmaeilzadeh and Aminpanah (2015) indicated that pod length and total pod yield traits showed non-significant differences for sowing dates.

Results in Tables (5-10) indicated that there were wide differences among the twenty five evaluated snap bean genotypes overall environments for all studied characters. For number of days to flowering trait, the genotype $G_{12}$ was consistently the earliest in all evaluated environments with a mean value of 30.33 days. Results indicated that genotype $\mathrm{G}_{1}$ gave the longest pod across all environments which gave mean value of $14.92 \mathrm{~cm}$ followed by $G_{18}$ which gave mean value of $14.89 \mathrm{~cm}$ with non-significant difference between them. On the other side, the lowest values of pod length were obtained for $\mathrm{G}_{12}(10.16 \mathrm{~cm})$, meanwhile, the check cultivars Bronco, Paulista, Samantha and Xera gave values of 12.45, 13.30, 13.04 and 11.56 $\mathrm{cm}$, respectively. Overall means of pod diameter of the 25 genotypes studied across environmental factors ranged from $6.47 \mathrm{~mm}$ for cultivar Samantha to $9.43 \mathrm{~mm}$ for genotype $\mathrm{G}_{12}$ with overall mean value of $7.25 \mathrm{~mm}$. At the overall combined analyses, recorded data showed that genotypes $G_{10}$ and $G_{6}$ possessed the lowest means of pod fiber content which gave mean values of 1.29 and 1.32 $\mathrm{g} / 100 \mathrm{~g}$ fresh pod weight, at the generally speaking consolidated examinations, recorded information demonstrated that genotypes G10, G6, G21 and Xera had the most minimal methods for pod fiber 
Table 5. Mean performance for number of days to flowering of twenty one and four chick(control) snap bean genotypes grown under different sowing dates $\left(D_{1}-D_{4}\right)$ during two seasons (2015/2016 and 2016/2017)

\begin{tabular}{|c|c|c|c|c|c|c|c|c|c|c|c|}
\hline \multirow{2}{*}{ Genotype } & \multicolumn{5}{|c|}{ First season $(2015 / 2016)$} & \multicolumn{5}{|c|}{ Second season $(2016 / 2017)$} & \multirow[t]{2}{*}{ Overall } \\
\hline & $D_{1}$ & $\mathrm{D}_{2}$ & $D_{3}$ & $D_{4}$ & Mean & $D_{1}$ & $D_{2}$ & $D_{3}$ & $D_{4}$ & Mean & \\
\hline $\mathrm{G}_{1}$ & 36.67 & 37.00 & 42.00 & 41.33 & 39.25 & 38.33 & 36.67 & 44.33 & 41.33 & 40.17 & 39.71 \\
\hline $\mathrm{G}_{2}$ & 38.67 & 35.67 & 45.67 & 44.33 & 41.09 & 38.67 & 38.67 & 48.33 & 44.67 & 42.59 & 41.84 \\
\hline $\mathrm{G}_{3}$ & 37.67 & 39.33 & 41.00 & 44.33 & 40.58 & 37.67 & 40.67 & 43.33 & 44.33 & 41.50 & 41.04 \\
\hline $\mathrm{G}_{4}$ & 38.33 & 39.33 & 43.33 & 42.67 & 40.92 & 38.33 & 40.00 & 45.67 & 42.67 & 41.67 & 41.29 \\
\hline $\mathrm{G}_{5}$ & 39.67 & 38.33 & 44.67 & 44.67 & 41.84 & 40.00 & 39.00 & 46.67 & 44.67 & 42.59 & 42.21 \\
\hline $\mathrm{G}_{6}$ & 35.00 & 38.33 & 37.33 & 42.67 & 38.33 & 35.67 & 39.33 & 39.67 & 42.67 & 39.34 & 38.83 \\
\hline $\mathrm{G}_{7}$ & 37.33 & 37.67 & 42.33 & 44.33 & 40.42 & 37.33 & 38.67 & 45.67 & 44.33 & 41.50 & 40.96 \\
\hline $\mathrm{G}_{8}$ & 36.33 & 37.67 & 42.33 & 43.67 & 40.00 & 38.00 & 39.33 & 43.67 & 44.33 & 41.33 & 40.67 \\
\hline $\mathrm{G}_{9}$ & 31.33 & 38.67 & 42.33 & 43.67 & 39.00 & 31.67 & 39.33 & 44.67 & 43.67 & 39.84 & 39.42 \\
\hline $\mathrm{G}_{10}$ & 36.67 & 37.00 & 40.67 & 42.33 & 39.17 & 39.33 & 38.33 & 42.67 & 43.33 & 40.92 & 40.04 \\
\hline $\mathrm{G}_{11}$ & 35.67 & 36.67 & 41.33 & 41.67 & 38.84 & 31.67 & 38.33 & 44.67 & 41.67 & 39.09 & 38.96 \\
\hline $\mathrm{G}_{12}$ & 25.67 & 29.00 & 34.67 & 30.00 & 29.84 & 27.67 & 30.33 & 35.33 & 30.00 & 30.83 & 30.33 \\
\hline $\mathrm{G}_{13}$ & 36.33 & 38.67 & 44.33 & 43.33 & 40.67 & 36.33 & 39.67 & 46.67 & 43.33 & 41.50 & 41.08 \\
\hline $\mathrm{G}_{14}$ & 36.67 & 36.67 & 44.33 & 42.67 & 40.09 & 36.67 & 38.67 & 45.67 & 43.00 & 41.00 & 40.54 \\
\hline $\mathrm{G}_{15}$ & 40.33 & 38.67 & 40.33 & 43.33 & 40.67 & 40.33 & 39.67 & 42.33 & 43.00 & 41.33 & 41.00 \\
\hline $\mathrm{G}_{16}$ & 40.33 & 40.67 & 48.33 & 46.33 & 43.92 & 37.67 & 40.33 & 49.33 & 46.33 & 43.42 & 43.67 \\
\hline $\mathrm{G}_{17}$ & 39.33 & 36.67 & 42.33 & 43.33 & 40.42 & 38.67 & 39.00 & 50.33 & 43.33 & 42.83 & 41.62 \\
\hline $\mathrm{G}_{18}$ & 36.67 & 37.00 & 41.33 & 43.33 & 39.58 & 36.67 & 38.33 & 50.67 & 43.33 & 42.25 & 40.92 \\
\hline $\mathrm{G}_{19}$ & 35.67 & 39.33 & 46.00 & 43.33 & 41.08 & 36.67 & 39.67 & 47.67 & 42.67 & 41.67 & 41.38 \\
\hline $\mathrm{G}_{20}$ & 39.33 & 39.33 & 42.33 & 45.33 & 41.58 & 39.67 & 40.67 & 43.67 & 45.33 & 42.34 & 41.96 \\
\hline $\mathrm{G}_{21}$ & 38.67 & 38.67 & 43.33 & 43.33 & 41.00 & 38.67 & 39.67 & 45.67 & 43.33 & 41.84 & 41.42 \\
\hline Bronco & 35.67 & 36.67 & 41.00 & 41.33 & 38.67 & 35.67 & 37.33 & 42.33 & 42.67 & 39.50 & 39.08 \\
\hline Paulista & 36.67 & 37.33 & 39.33 & 42.33 & 38.92 & 36.67 & 36.67 & 42.67 & 42.67 & 39.67 & 39.29 \\
\hline Samantha & 35.33 & 36.67 & 45.33 & 42.33 & 39.92 & 36.67 & 39.33 & 47.33 & 41.67 & 41.25 & 40.58 \\
\hline Xera & 39.00 & 37.33 & 40.00 & 41.33 & 39.42 & 39.00 & 38.67 & 42.00 & 41.33 & 40.25 & 39.83 \\
\hline Mean & 36.76 & 37.53 & 42.24 & 42.69 & 39.81 & 36.95 & 38.65 & 44.84 & 42.79 & 40.81 & 40.31 \\
\hline \multicolumn{12}{|l|}{ L.S.D. $5 \%$} \\
\hline $\begin{array}{c}Y \\
D \\
Y D\end{array}$ & & & & & 3 & & & & & 32 & $\begin{array}{l}0.13 \\
0.18 \\
0.26\end{array}$ \\
\hline G & 0.98 & 0.93 & 0.91 & 0.95 & 0.91 & 0.87 & 0.88 & 0.88 & 0.97 & 0.45 & 0.31 \\
\hline GY & & & & & & & & & & & 0.44 \\
\hline GD & & & & & 1.82 & & & & & 0.89 & 0.62 \\
\hline GYD & & & & & & & & & & & 0.88 \\
\hline
\end{tabular}



economic characters in snap bean

Table 6. Mean performance for pod length $(\mathrm{cm})$ of twenty one and four chick (control) snap bean genotypes grown under different sowing dates $\left(D_{1}-D_{4}\right)$ during two seasons $(2015 / 2016$ and 2016/2017)

\begin{tabular}{|c|c|c|c|c|c|c|c|c|c|c|c|}
\hline \multirow{2}{*}{ Genotype } & \multicolumn{5}{|c|}{ First season $(2015 / 2016)$} & \multicolumn{5}{|c|}{ Second season (2016/2017) } & \multirow{2}{*}{ Overal } \\
\hline & $\mathrm{D}_{1}$ & $\mathrm{D}_{2}$ & $\mathrm{D}_{3}$ & $\mathrm{D}_{4}$ & Mean & $\mathrm{D}_{1}$ & $\mathrm{D}_{2}$ & $\mathrm{D}_{3}$ & $\mathrm{D}_{4}$ & Mean & \\
\hline $\mathrm{G}_{1}$ & 14.47 & 15.15 & 14.87 & 14.9 & 14.85 & 14.57 & 14.8 & 15.39 & 15.18 & 14.99 & 14.92 \\
\hline $\mathrm{G}_{2}$ & 14.15 & 14.6 & 13.31 & 14.39 & 14.11 & 13.80 & 14.55 & 15.7 & 15.58 & 14.91 & 14.51 \\
\hline $\mathrm{G}_{3}$ & 12.94 & 13.73 & 12.66 & 13.33 & 13.17 & 13.34 & 13.88 & 14.05 & 14.31 & 13.90 & 13.53 \\
\hline $\mathrm{G}_{4}$ & 12.47 & 13.39 & 12.69 & 13.33 & 12.97 & 13.14 & 12.81 & 13.80 & 13.41 & 13.29 & 13.13 \\
\hline $\mathrm{G}_{5}$ & 12.94 & 12.52 & 12.67 & 12.70 & 12.71 & 12.89 & 12.59 & 12.59 & 12.64 & 12.68 & 12.69 \\
\hline $\mathrm{G}_{6}$ & 13.63 & 14.76 & 13.87 & 14.73 & 14.25 & 13.48 & 15.02 & 15.50 & 15.16 & 14.79 & 14.52 \\
\hline $\mathrm{G}_{7}$ & 15.42 & 14.17 & 13.87 & 14.59 & 14.51 & 13.82 & 13.96 & 14.15 & 15.87 & 14.45 & 14.48 \\
\hline $\mathrm{G}_{8}$ & 13.72 & 14.17 & 13.51 & 13.27 & 13.67 & 13.40 & 13.54 & 14.56 & 14.85 & 14.09 & 13.88 \\
\hline $\mathrm{G}_{9}$ & 14.63 & 14.79 & 13.84 & 14.51 & 14.44 & 14.09 & 13.58 & 15.21 & 15.33 & 14.55 & 14.50 \\
\hline $\mathrm{G}_{10}$ & 12.61 & 14.65 & 12.76 & 13.47 & 13.37 & 12.54 & 13.23 & 14.75 & 14.82 & 13.84 & 13.60 \\
\hline $\mathrm{G}_{11}$ & 11.59 & 13.52 & 12.48 & 11.55 & 12.29 & 13.71 & 12.82 & 12.77 & 12.44 & 12.94 & 12.61 \\
\hline $\mathrm{G}_{12}$ & 8.92 & 10.45 & 9.98 & 10.80 & 10.04 & 10.19 & 10.48 & 10.49 & 9.99 & 10.29 & 10.16 \\
\hline $\mathrm{G}_{13}$ & 12.44 & 14.84 & 12.17 & 12.57 & 13.01 & 13.52 & 12.68 & 12.63 & 13.48 & 13.08 & 13.04 \\
\hline $\mathrm{G}_{14}$ & 11.16 & 12.59 & 12.37 & 12.44 & 12.14 & 13.52 & 12.52 & 12.74 & 12.11 & 12.72 & 12.43 \\
\hline $\mathrm{G}_{15}$ & 11.58 & 12.13 & 12.54 & 12.64 & 12.22 & 11.56 & 12.57 & 13.15 & 13.22 & 12.63 & 12.42 \\
\hline $\mathrm{G}_{16}$ & 14.78 & 14.15 & 14.28 & 14.40 & 14.40 & 14.58 & 14.26 & 14.46 & 14.47 & 14.44 & 14.42 \\
\hline $\mathrm{G}_{17}$ & 13.39 & 13.79 & 13.33 & 13.87 & 13.60 & 12.79 & 11.56 & 14.72 & 14.35 & 13.36 & 13.48 \\
\hline $\mathrm{G}_{18}$ & 14.54 & 14.94 & 14.31 & 15.65 & 14.86 & 13.40 & 14.46 & 15.52 & 16.31 & 14.92 & 14.89 \\
\hline $\mathrm{G}_{19}$ & 11.55 & 12.52 & 12.03 & 12.32 & 12.11 & 12.37 & 11.87 & 13.65 & 12.68 & 12.64 & 12.37 \\
\hline $\mathrm{G}_{20}$ & 11.41 & 13.56 & 11.66 & 13.22 & 12.46 & 12.59 & 13.37 & 13.24 & 14.32 & 13.38 & 12.92 \\
\hline $\mathrm{G}_{21}$ & 14.13 & 14.56 & 14.23 & 14.77 & 14.42 & 13.38 & 14.28 & 15.42 & 14.90 & 14.50 & 14.46 \\
\hline Bronco & 12.38 & 12.63 & 12.20 & 12.71 & 12.48 & 12.10 & 12.56 & 12.37 & 12.62 & 12.41 & 12.45 \\
\hline Paulista & 12.65 & 13.44 & 13.34 & 13.44 & 13.22 & 13.46 & 13.47 & 13.10 & 13.48 & 13.38 & 13.30 \\
\hline Samantha & 11.67 & 13.09 & 13.20 & 13.65 & 12.90 & 12.09 & 13.54 & 13.32 & 13.79 & 13.19 & 13.04 \\
\hline Xera & 11.82 & 11.40 & 11.13 & 11.50 & 11.46 & 11.66 & 11.61 & 11.81 & 11.52 & 11.65 & 11.56 \\
\hline Mean & 12.84 & 13.58 & 12.93 & 13.39 & 13.19 & 13.04 & 13.20 & 13.80 & 13.87 & 13.48 & 13.33 \\
\hline \multicolumn{12}{|l|}{ L.S.D.5\% } \\
\hline $\begin{array}{c}Y \\
D \\
Y D\end{array}$ & & & & & 0.07 & & & & & 0.07 & $\begin{array}{l}0.01 \\
0.02 \\
0.02\end{array}$ \\
\hline G & 0.54 & 0.50 & 0.31 & 0.43 & 0.28 & 0.59 & 0.43 & 0.34 & 0.49 & 0.20 & 0.17 \\
\hline $\begin{array}{l}\text { GY } \\
\text { GD }\end{array}$ & & & & & & & & & & & $\begin{array}{l}0.24 \\
0.35\end{array}$ \\
\hline $\begin{array}{l}\text { GD } \\
\text { GYD }\end{array}$ & & & & & 0.56 & & & & & 0.40 & $\begin{array}{l}0.35 \\
0.49\end{array}$ \\
\hline
\end{tabular}


Table 7. Mean performance for pod diameter $(\mathrm{mm})$ of twenty one and four chick (control) snap bean genotypes grown under different sowing dates $\left(D_{1}-D_{4}\right)$ during two seasons $(2015 / 2016$ and $2016 / 2017)$

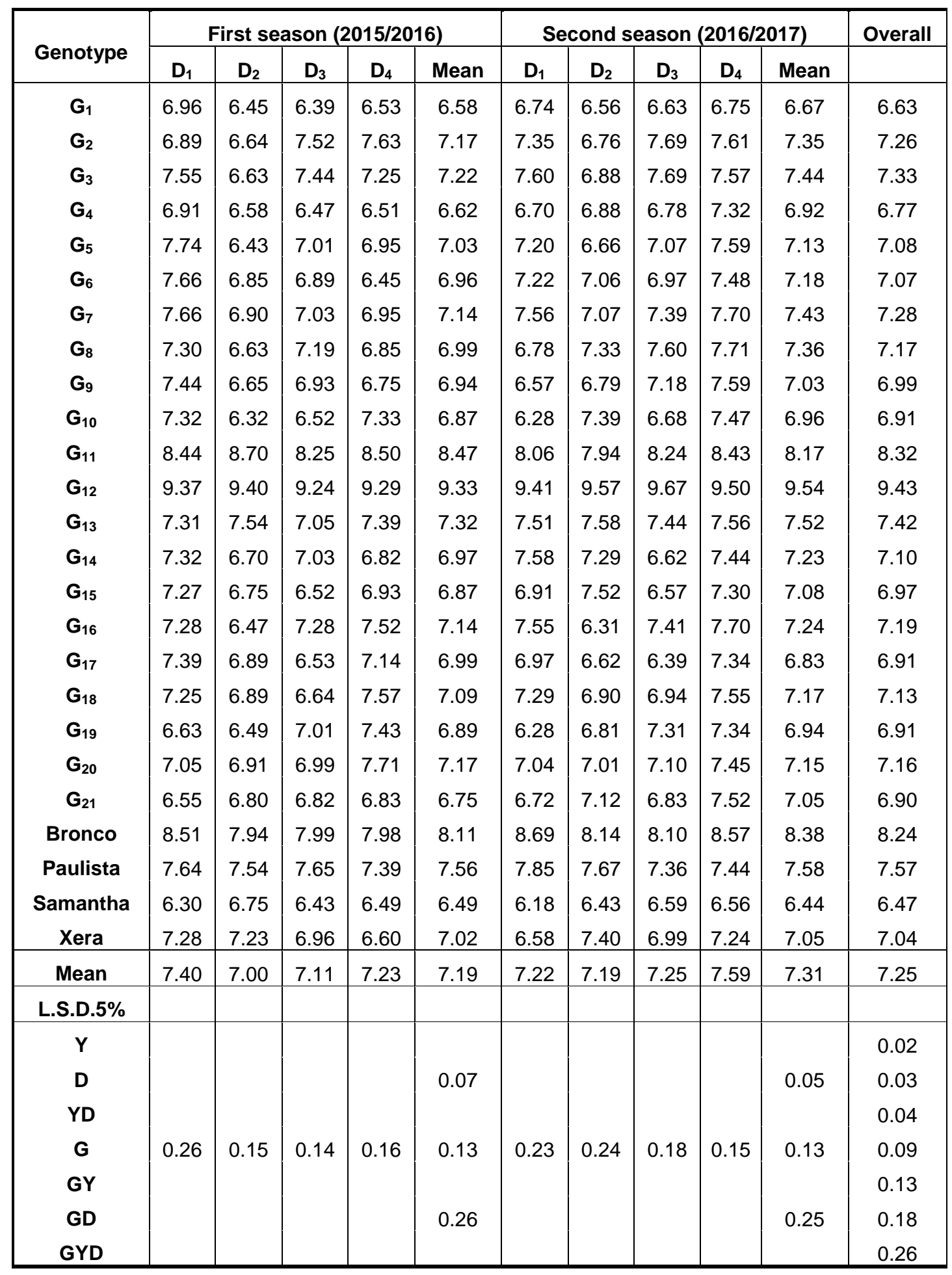



economic characters in snap bean

Table 8. Mean performance for pods fiber content ( $\mathrm{g} / 100 \mathrm{~g}$ fresh pod weight) of twenty one and four chick (control) snap bean genotypes grown under different sowing dates $\left(D_{1}-D_{4}\right)$ during two seasons (2015/2016 and 2016/2017).

\begin{tabular}{|c|c|c|c|c|c|c|c|c|c|c|c|}
\hline \multirow{2}{*}{ Genotype } & \multicolumn{5}{|c|}{ First season $(2015 / 2016)$} & \multicolumn{5}{|c|}{ Second season $(2016 / 2017)$} & \multirow{2}{*}{ Overall } \\
\hline & $\mathrm{D}_{1}$ & $\mathrm{D}_{2}$ & $\mathrm{D}_{3}$ & $\mathrm{D}_{4}$ & Mean & $D_{1}$ & $\mathrm{D}_{2}$ & $D_{3}$ & $\mathrm{D}_{4}$ & Mean & \\
\hline $\mathrm{G}_{1}$ & 1.41 & 1.47 & 1.35 & 1.47 & 1.43 & 1.36 & 1.45 & 1.74 & 1.14 & 1.42 & 1.42 \\
\hline $\mathrm{G}_{2}$ & 1.47 & 1.42 & 1.43 & 1.55 & 1.47 & 1.40 & 1.44 & 1.63 & 1.11 & 1.40 & 1.43 \\
\hline $\mathrm{G}_{3}$ & 1.70 & 1.62 & 1.75 & 1.62 & 1.67 & 1.58 & 1.55 & 1.23 & 1.75 & 1.53 & 1.60 \\
\hline $\mathrm{G}_{4}$ & 1.53 & 1.30 & 1.68 & 1.27 & 1.45 & 1.30 & 1.79 & 1.46 & 1.30 & 1.46 & 1.45 \\
\hline $\mathrm{G}_{5}$ & 1.05 & 1.73 & 1.43 & 1.76 & 1.49 & 1.31 & 1.21 & 1.51 & 1.36 & 1.35 & 1.42 \\
\hline $\mathbf{G}_{6}$ & 1.44 & 1.32 & 1.33 & 1.32 & 1.35 & 1.26 & 1.23 & 1.57 & 1.09 & 1.29 & 1.32 \\
\hline $\mathrm{G}_{7}$ & 1.45 & 1.31 & 1.42 & 1.31 & 1.37 & 1.62 & 1.43 & 1.59 & 1.74 & 1.60 & 1.48 \\
\hline $\mathrm{G}_{8}$ & 1.00 & 1.71 & 1.62 & 1.71 & 1.51 & 1.11 & 1.23 & 1.58 & 1.16 & 1.27 & 1.39 \\
\hline $\mathrm{G}_{9}$ & 1.61 & 1.27 & 1.74 & 1.27 & 1.47 & 1.44 & 1.51 & 1.77 & 1.41 & 1.53 & 1.50 \\
\hline$G_{10}$ & 1.12 & 1.26 & 1.54 & 1.26 & 1.30 & 1.18 & 1.38 & 1.27 & 1.32 & 1.29 & 1.29 \\
\hline $\mathbf{G}_{11}$ & 1.26 & 1.59 & 1.27 & 1.76 & 1.47 & 1.74 & 1.43 & 1.55 & 1.60 & 1.58 & 1.53 \\
\hline $\mathrm{G}_{12}$ & 1.92 & 1.85 & 1.89 & 1.85 & 1.88 & 1.91 & 1.82 & 1.92 & 1.47 & 1.78 & 1.83 \\
\hline $\mathrm{G}_{13}$ & 1.40 & 1.90 & 1.64 & 1.90 & 1.71 & 1.51 & 1.03 & 1.53 & 1.43 & 1.38 & 1.54 \\
\hline $\mathbf{G}_{14}$ & 1.41 & 1.30 & 1.56 & 1.30 & 1.39 & 1.37 & 1.24 & 1.58 & 1.42 & 1.40 & 1.40 \\
\hline $\mathrm{G}_{15}$ & 1.03 & 1.70 & 1.24 & 1.70 & 1.42 & 1.43 & 1.63 & 1.18 & 1.45 & 1.42 & 1.42 \\
\hline$G_{16}$ & 1.02 & 1.51 & 1.54 & 1.51 & 1.40 & 1.58 & 1.43 & 1.41 & 1.30 & 1.43 & 1.41 \\
\hline $\mathrm{G}_{17}$ & 1.34 & 1.44 & 1.43 & 1.44 & 1.41 & 1.66 & 1.51 & 1.33 & 1.21 & 1.43 & 1.42 \\
\hline$G_{18}$ & 1.45 & 1.28 & 1.60 & 1.28 & 1.40 & 1.48 & 1.50 & 1.59 & 1.55 & 1.53 & 1.47 \\
\hline$G_{19}$ & 1.31 & 1.14 & 1.34 & 1.14 & 1.23 & 1.63 & 1.33 & 1.67 & 1.55 & 1.55 & 1.39 \\
\hline $\mathrm{G}_{20}$ & 1.11 & 1.14 & 1.32 & 1.67 & 1.31 & 1.30 & 1.48 & 1.75 & 1.57 & 1.53 & 1.42 \\
\hline $\mathrm{G}_{21}$ & 1.05 & 1.06 & 1.55 & 1.06 & 1.18 & 1.30 & 1.63 & 1.55 & 1.53 & 1.50 & 1.34 \\
\hline Bronco & 1.14 & 1.72 & 1.35 & 1.72 & 1.48 & 1.42 & 1.59 & 1.72 & 1.87 & 1.65 & 1.57 \\
\hline Paulista & 1.16 & 1.53 & 1.82 & 1.53 & 1.51 & 1.40 & 1.74 & 1.50 & 1.43 & 1.52 & 1.51 \\
\hline Samantha & 1.45 & 1.37 & 1.57 & 1.37 & 1.44 & 1.30 & 1.29 & 1.34 & 1.42 & 1.34 & 1.39 \\
\hline Xera & 1.34 & 1.10 & 1.60 & 1.07 & 1.28 & 1.45 & 1.53 & 1.51 & 1.45 & 1.49 & 1.38 \\
\hline Mean & 1.33 & 1.44 & 1.52 & 1.47 & 1.44 & 1.44 & 1.46 & 1.54 & 1.43 & 1.47 & 1.45 \\
\hline \multicolumn{12}{|l|}{ L.S.D.5\% } \\
\hline $\mathbf{Y}$ & & & & & & & & & & & 0.02 \\
\hline D & & & & & 0.10 & & & & & 0.08 & 0.02 \\
\hline YD & & & & & & & & & & & 0.03 \\
\hline G & 0.10 & 0.30 & 0.43 & 0.28 & 0.10 & 0.34 & 0.34 & 0.42 & 0.28 & 0.10 & 0.07 \\
\hline GY & & & & & & & & & & & 0.11 \\
\hline GD & & & & & 0.20 & & & & & 0.21 & 0.15 \\
\hline GYD & & & & & & & & & & & 0.21 \\
\hline
\end{tabular}


Table 9. Mean performance for total green yield (ton/fed.dan) of twenty one and four chick (control) snap bean genotypes grown under different sowing dates $\left(D_{1}-D_{4}\right)$ during two seasons $(2015 / 2016$ and 2016/2017).

\begin{tabular}{|c|c|c|c|c|c|c|c|c|c|c|c|}
\hline \multirow{2}{*}{ Genotype } & \multicolumn{5}{|c|}{ First season $(2015 / 2016)$} & \multicolumn{5}{|c|}{ Second season $(2016 / 2017)$} & \multirow{2}{*}{ Overall } \\
\hline & $\mathrm{D}_{1}$ & $D_{2}$ & $D_{3}$ & $\mathrm{D}_{4}$ & Mean & $\mathrm{D}_{1}$ & $\mathrm{D}_{2}$ & $D_{3}$ & $\mathrm{D}_{4}$ & Mean & \\
\hline $\mathrm{G}_{1}$ & 3.74 & 3.95 & 5.65 & 5.06 & 4.60 & 3.41 & 4.80 & 5.46 & 5.53 & 4.80 & 4.77 \\
\hline $\mathrm{G}_{2}$ & 4.14 & 4.61 & 5.41 & 4.74 & 4.73 & 4.06 & 4.17 & 5.49 & 5.05 & 4.69 & 4.70 \\
\hline $\mathrm{G}_{3}$ & 2.99 & 4.39 & 4.75 & 4.27 & 4.10 & 3.65 & 5.24 & 5.11 & 3.99 & 4.50 & 4.30 \\
\hline $\mathrm{G}_{4}$ & 3.79 & 4.07 & 4.51 & 3.94 & 4.08 & 3.7 & 3.90 & 4.94 & 4.47 & 4.25 & 4.17 \\
\hline $\mathrm{G}_{5}$ & 3.40 & 4.2 & 4.42 & 4.29 & 4.08 & 3.42 & 4.24 & 4.91 & 4.52 & 4.27 & 4.18 \\
\hline $\mathrm{G}_{6}$ & 3.17 & 4.16 & 5.95 & 3.88 & 4.29 & 2.93 & 4.38 & 5.85 & 4.57 & 4.43 & 4.36 \\
\hline $\mathrm{G}_{7}$ & 4.15 & 4.79 & 4.48 & 3.71 & 4.28 & 3.99 & 4.81 & 4.04 & 4.32 & 4.29 & 4.29 \\
\hline $\mathrm{G}_{8}$ & 4.85 & 5.16 & 5.19 & 3.75 & 4.74 & 3.97 & 6.07 & 5.62 & 4.80 & 5.12 & 4.93 \\
\hline $\mathrm{G}_{9}$ & 3.04 & 4.53 & 4.73 & 4.29 & 4.15 & 3.32 & 3.81 & 4.71 & 4.31 & 4.04 & 4.09 \\
\hline$G_{10}$ & 4.24 & 5.27 & 5.15 & 3.72 & 4.60 & 4.85 & 5.43 & 4.59 & 4.02 & 4.72 & 4.67 \\
\hline$G_{11}$ & 3.57 & 4.51 & 3.74 & 3.17 & 3.75 & 3.81 & 4.30 & 4.00 & 3.53 & 3.91 & 3.83 \\
\hline $\mathrm{G}_{12}$ & 3.98 & 4.18 & 3.39 & 2.74 & 3.57 & 3.98 & 3.89 & 4.03 & 2.95 & 3.71 & 3.64 \\
\hline $\mathrm{G}_{13}$ & 4.12 & 4.88 & 3.56 & 2.89 & 3.86 & 3.59 & 4.58 & 3.78 & 3.11 & 3.77 & 3.82 \\
\hline $\mathrm{G}_{14}$ & 3.18 & 5.05 & 4.29 & 3.04 & 3.89 & 3.65 & 3.76 & 3.64 & 3.33 & 3.60 & 3.74 \\
\hline $\mathrm{G}_{15}$ & 4.11 & 5.12 & 3.87 & 3.38 & 4.12 & 4.29 & 5.24 & 4.66 & 2.78 & 4.24 & 4.19 \\
\hline $\mathrm{G}_{16}$ & 3.65 & 4.52 & 4.49 & 3.08 & 3.94 & 3.69 & 4.32 & 4.06 & 3.05 & 3.78 & 3.86 \\
\hline$G_{17}$ & 2.84 & 3.51 & 3.82 & 2.71 & 3.22 & 3.19 & 3.48 & 3.39 & 3.32 & 3.35 & 3.28 \\
\hline $\mathrm{G}_{18}$ & 4.32 & 5.13 & 5.00 & 3.47 & 4.48 & 4.00 & 4.16 & 5.05 & 4.54 & 4.44 & 4.47 \\
\hline $\mathrm{G}_{19}$ & 2.17 & 3.96 & 3.50 & 3.33 & 3.24 & 2.84 & 3.20 & 4.08 & 3.52 & 3.41 & 3.33 \\
\hline $\mathrm{G}_{20}$ & 2.90 & 3.53 & 3.65 & 2.80 & 3.22 & 3.41 & 3.90 & 3.52 & 3.06 & 3.47 & 3.35 \\
\hline $\mathrm{G}_{21}$ & 3.21 & 3.80 & 3.36 & 3.46 & 3.46 & 2.83 & 4.47 & 3.90 & 3.99 & 3.80 & 3.63 \\
\hline Bronco & 4.24 & 5.37 & 5.39 & 4.92 & 4.98 & 3.80 & 5.16 & 4.53 & 4.18 & 4.42 & 4.70 \\
\hline Paulista & 4.26 & 4.34 & 5.60 & 4.69 & 4.72 & 4.16 & 4.20 & 5.46 & 4.63 & 4.61 & 4.67 \\
\hline Samantha & 3.26 & 3.86 & 4.02 & 3.78 & 3.73 & 3.16 & 3.61 & 4.22 & 3.52 & 3.63 & 3.68 \\
\hline Xera & 3.78 & 5.14 & 4.96 & 3.75 & 4.41 & 3.87 & 4.89 & 5.59 & 4.56 & 4.73 & 4.57 \\
\hline Mean & 3.64 & 4.48 & 4.52 & 3.71 & 4.09 & 3.66 & 4.40 & 4.59 & 3.99 & 4.16 & 4.12 \\
\hline L.S.D.5\% & & & & & & & & & & & \\
\hline $\begin{array}{c}Y \\
D \\
\text { YD } \\
\text { G } \\
\text { GY } \\
\text { GD } \\
\text { GYD } \\
\end{array}$ & 0.35 & 0.40 & 0.37 & 0.46 & $\begin{array}{l}0.41 \\
1.05 \\
2.10\end{array}$ & 0.48 & 0.47 & 0.36 & 0.28 & $\begin{array}{l}0.22 \\
0.45\end{array}$ & $\begin{array}{l}0.04 \\
0.05 \\
0.08 \\
0.14 \\
0.20 \\
0.29 \\
0.41 \\
\end{array}$ \\
\hline
\end{tabular}



economic characters in snap bean

Table 10. Mean performance for rust disease severity (\%) of twenty one and four chick (control) snap bean genotypes grown under different sowing dates $\left(D_{1}-D_{4}\right)$ during two seasons (2015/2016 and 2016/2017).

\begin{tabular}{|c|c|c|c|c|c|c|c|c|c|c|c|}
\hline \multirow{2}{*}{ Genotype } & \multicolumn{5}{|c|}{ First season $(2015 / 2016)$} & \multicolumn{5}{|c|}{ Second season $(2016 / 2017)$} & \multirow[b]{2}{*}{ Overall } \\
\hline & $\mathrm{D}_{1}$ & $\mathrm{D}_{2}$ & $\mathbf{D}_{3}$ & $\mathrm{D}_{4}$ & Mean & $\mathrm{D}_{1}$ & $\mathrm{D}_{2}$ & $\mathbf{D}_{3}$ & $\mathrm{D}_{4}$ & Mean & \\
\hline $\mathrm{G}_{1}$ & 0.00 & 0.00 & 0.00 & 0.00 & 0.00 & 0.00 & 0.00 & 0.00 & 0.00 & 0.00 & 0.00 \\
\hline $\mathrm{G}_{2}$ & 0.00 & 0.00 & 0.00 & 0.00 & 0.00 & 0.00 & 0.00 & 0.00 & 0.00 & 0.00 & 0.00 \\
\hline $\mathrm{G}_{3}$ & 0.00 & 0.00 & 0.00 & 0.00 & 0.00 & 0.00 & 0.00 & 0.00 & 0.00 & 0.00 & 0.00 \\
\hline $\mathrm{G}_{4}$ & 0.00 & 0.00 & 0.00 & 0.00 & 0.00 & 0.00 & 0.00 & 0.00 & 0.00 & 0.00 & 0.00 \\
\hline $\mathrm{G}_{5}$ & 0.00 & 0.00 & 0.00 & 0.00 & 0.00 & 0.00 & 0.00 & 0.00 & 0.00 & 0.00 & 0.00 \\
\hline $\mathrm{G}_{6}$ & 0.00 & 0.00 & 0.00 & 0.00 & 0.00 & 0.00 & 0.00 & 0.00 & 0.00 & 0.00 & 0.00 \\
\hline $\mathrm{G}_{7}$ & 0.00 & 0.00 & 0.00 & 0.00 & 0.00 & 0.00 & 0.00 & 0.00 & 0.00 & 0.00 & 0.00 \\
\hline $\mathrm{G}_{8}$ & 0.00 & 0.00 & 0.00 & 0.00 & 0.00 & 0.00 & 0.00 & 0.00 & 0.00 & 0.00 & 0.00 \\
\hline $\mathrm{G}_{9}$ & 0.00 & 0.00 & 0.00 & 0.00 & 0.00 & 0.00 & 0.00 & 0.00 & 0.00 & 0.00 & 0.00 \\
\hline $\mathbf{G}_{10}$ & 3.66 & 11.00 & 43.33 & 11.66 & 17.41 & 8.00 & 16.66 & 33.33 & 8.00 & 16.50 & 16.96 \\
\hline $\mathrm{G}_{11}$ & 11.66 & 50.00 & 45.00 & 43.33 & 37.50 & 16.66 & 48.33 & 36.66 & 33.33 & 33.75 & 35.62 \\
\hline $\mathrm{G}_{12}$ & 13.33 & 47.33 & 60.00 & 50.00 & 42.67 & 30.00 & 50.00 & 36.66 & 35.00 & 37.92 & 40.29 \\
\hline $\mathrm{G}_{13}$ & 0.00 & 0.00 & 0.00 & 0.00 & 0.00 & 0.00 & 0.00 & 0.00 & 0.00 & 0.00 & 0.00 \\
\hline $\mathrm{G}_{14}$ & 0.00 & 0.00 & 0.00 & 0.00 & 0.00 & 0.00 & 0.00 & 0.00 & 0.00 & 0.00 & 0.00 \\
\hline $\mathbf{G}_{15}$ & 0.00 & 0.00 & 0.00 & 0.00 & 0.00 & 0.00 & 0.00 & 0.00 & 0.00 & 0.00 & 0.00 \\
\hline $\mathbf{G}_{16}$ & 0.00 & 0.00 & 0.00 & 0.00 & 0.00 & 0.00 & 0.00 & 0.00 & 0.00 & 0.00 & 0.00 \\
\hline $\mathrm{G}_{17}$ & 0.00 & 0.00 & 0.00 & 0.00 & 0.00 & 0.00 & 0.00 & 0.00 & 0.00 & 0.00 & 0.00 \\
\hline $\mathrm{G}_{18}$ & 0.00 & 0.00 & 0.00 & 0.00 & 0.00 & 0.00 & 0.00 & 0.00 & 0.00 & 0.00 & 0.00 \\
\hline $\mathrm{G}_{19}$ & 0.00 & 0.00 & 0.00 & 0.00 & 0.00 & 0.00 & 0.00 & 0.00 & 0.00 & 0.00 & 0.00 \\
\hline $\mathrm{G}_{20}$ & 0.00 & 0.00 & 0.00 & 0.00 & 0.00 & 0.00 & 0.00 & 0.00 & 0.00 & 0.00 & 0.00 \\
\hline $\mathrm{G}_{21}$ & 0.00 & 0.00 & 0.00 & 0.00 & 0.00 & 0.00 & 0.00 & 0.00 & 0.00 & 0.00 & 0.00 \\
\hline Bronco & 20.33 & 40 & 53.33 & 43.33 & 39.25 & 28.33 & 43.33 & 36.66 & 40.00 & 37.08 & 38.16 \\
\hline Paulista & 16.00 & 46.33 & 33.33 & 36.66 & 33.08 & 10.00 & 46.66 & 26.66 & 28.33 & 27.91 & 30.50 \\
\hline Samantha & 8.00 & 52.33 & 50.00 & 31.66 & 35.50 & 5.66 & 50.00 & 36.66 & 23.33 & 28.91 & 32.21 \\
\hline Xera & 10.00 & 37.33 & 21.66 & 16.66 & 21.41 & 7.00 & 38.33 & 11.66 & 11.66 & 17.16 & 19.29 \\
\hline Mean & 3.32 & 11.37 & 12.27 & 9.33 & 9.07 & 4.23 & 11.73 & 8.73 & 7.19 & 7.97 & 8.52 \\
\hline \multicolumn{12}{|l|}{ L.S.D.5\% } \\
\hline $\begin{array}{c}Y \\
D \\
\text { YD }\end{array}$ & & & & & 1.42 & & & & & 0.58 & $\begin{array}{l}0.27 \\
0.39 \\
0.55\end{array}$ \\
\hline $\begin{array}{c}\text { G } \\
\text { GY } \\
\text { GD } \\
\text { GYD }\end{array}$ & 1.18 & 2.70 & 2.17 & 3.21 & 1.52 & 1.47 & 2.34 & 1.74 & 1.64 & 0.89 & $\begin{array}{l}0.77 \\
1.09 \\
1.54 \\
2.18\end{array}$ \\
\hline
\end{tabular}


content which gave mean estimations of 1.29 , $1.32,1.34$ and $1.38 \mathrm{~g} / 100 \mathrm{~g}$. Data recorded on total green yield showed that genotype $G_{8}$ gave the highest yield ( 4.93 tons) followed by $\mathrm{G}_{1}$ ( 4.77 tons) with significant difference between them, reflecting increases of about $5.58 \%$ and $1.70 \%$ comparing with the highest check cultivar Bronco (4.70 tons), respectively. Among 21 breeding lines evaluated, 18 lines showed absolute resistance against rust in all sowing dates (Table 10). These 18 promising lines proved superiority than all evaluated commercial cultivars for this character. However, three breeding lines $\left(G_{10}, G_{11}\right.$ and $\left.G_{12}\right)$ showed variable severity over the eight sowing dates of investigation and rated as susceptible genotypes (16.96$40.29 \%$ ). While, the check cultivars viz., Bronco, Paulista, Samantha and Xera cultivars were rated as susceptible (19.29-38.16\%). Similar results were obtained by Yoldas and Esiyok (2007), Hamed et al (2012), Getachew et al (2014a and b), Pereira et al (2014), Seyum (2014), Getachew et al (2015), Mounir et al (2015), Swegarden et al (2016), Hamed and Muhanna (2017) and Tadesse et al (2017) who found differential responses among genotypes under varying environments. However, Getachew et al (2014a) found that pod length and grain yield traits were non-significantly influenced by different varieties. Also, Getachew et al (2015) who found nonsignificant differences among studied cultivars for fibers content trait.

With regard to the interaction effects, data showed that the first and second order interactions were significant for all studied traits. Concerning $G$ $X Y \times D$ interaction effect, the earliest flowering value was obtained by line $\mathrm{G}_{12}$ (25.67 days) when cultivated in $1^{\text {st }}$ September in the first year. Results indicated that the longest pods $(16.31 \mathrm{~cm})$ were obtained by line $\mathrm{G}_{18}$ under the summer season in March in the second year. The highest value of pod diameter $\left(9.67 \mathrm{~mm}\right.$ ) was obtained by line $\mathrm{G}_{12}$ in second year at early summer sowing date (February), while Samantha gave the lowest value $(6.18 \mathrm{~mm})$ in the second year at early autumn sowing date (September). The lowest value of pod fiber content was obtained by genotype $\mathrm{G}_{8}(1.00 \%)$ in the early autumn sowing date (September) in the first year. The highest value of total green yield was obtained by $\mathrm{G}_{8}$ (6.07 tones) in the second year at late fall sowing date (October). For rust disease severity trait, the highest value was obtained by commercial cultivar Bronco (53.33\%) in early summer date in the first year followed by commercial cultivar Samantha $(52.33 \%)$ in late fall date in the first year without significant difference between them. On the contrary, the lowest values were obtained by the lines of $G_{1}, G_{2}, G_{3}, G_{4}, G_{5}$, $G_{6}, G_{7}, G_{8}, G_{9}, G_{13}, G_{14}, G_{15}, G_{16}, G_{17}, G_{18}, G_{19}$, $G_{20}$ and $G_{21}(0.00 \%)$ at all sowing dates. These results are in accordance with Khalifa et al (2013), Getachew et al (2014a and b), Pereira et al (2014), Seyum (2014), Getachew et al (2015), Hussein and Abd El-Hady (2015), Mounir et al (2015), Swegarden et al (2016) and Tadesse et al (2017) who found significant influence by interaction effect of variety and sowing date on these traits. However, non-significant interaction effect was found between varieties and sowing dates on total pod yield of green bean (Getachew et al 2014a, Getachew et al 2014b, Seyum, 2014 and Getachew et al 2015).

\section{Estimates of stability parameters}

Data in Table (11) showed that the linear response of different environments was highly significant for total green yield trait, indicating that genotypes differed in their regression on the environmental index. Therefore, the regression coefficient $\left(b_{i}\right)$ and deviation from regression $\left(S_{d}^{2}\right)$ was calculated. The mean square due to Env. + $(G \times E n v)$ was highly significant, indicating that genotypes considerable interacted with the eight environmental conditions. These results agree with those found by Pereira et al (2014) and Swegarden et al (2016).

Stability parameters which calculated from the total 8 environments using Eberhart and Russell (1966) model are given in Table 11. Obtained results show that the regression coefficients $\left(b_{i}\right)$ were not significantly different from 1.0 in twenty three genotypes for total yield trait and the $b$ values ranged between $0.43\left(\mathrm{G}_{12}\right)$ and $2.11\left(\mathrm{G}_{6}\right)$. Residual mean square values $\left(S_{d}^{2}\right)$, which are indicative of deviations from the regression, were close to 0.0 in the genotype $\mathrm{G}_{17}$ and cultivar Samantha $\left(S_{d}^{2}=0.02\right)$, while cultivar Xera had the highest $S^{2}{ }_{d}$ (4.52). The other genotypes $b_{i}$ and $S_{d}^{2}$ values were between these values for total yield trait.

It could be mentioned that the performance of a genotype which had non-significant regression coefficients $(b=1)$ may be predicted and said to be stable (Eberhart and Russell 1966). Generally, preferred genotypes show low $\mathrm{G} \times \mathrm{E}$ interaction variance, high mean yield potential over environments and below deviation from the expected 

economic characters in snap bean

Table 11. Stability analysis of variance and parameters for total green yield of twenty one and four chick (control) snap bean genotypes grown under different sowing dates during two seasons (2015/2016 and 2016/2017).

\begin{tabular}{|c|c|c|c|c|c|}
\hline \multirow{2}{*}{$\begin{array}{c}\text { Genotype and source } \\
\text { of variation }\end{array}$} & \multicolumn{5}{|c|}{$\begin{array}{l}\text { Total green yield } \\
\text { (ton /fed.dan) }\end{array}$} \\
\hline & Df & $\begin{array}{c}\text { Mean } \\
\text { squares }\end{array}$ & $\mathbf{x}$ & $\mathbf{b}_{\mathrm{i}}$ & $S_{d}^{2}$ \\
\hline Genotypes (G) & 24 & $2.21^{* *}$ & & & \\
\hline Env.+(G.×Env.) & 175 & $1.45^{\star *}$ & & & \\
\hline Env. (linear) & 1 & $146.60^{* *}$ & & & \\
\hline G.×Env. (linear) & 24 & $0.93^{*}$ & & & \\
\hline Pooled deviation & 150 & 0.57 & & & \\
\hline $\mathrm{G}_{1}$ & 6 & 0.27 & 4.765 & 1.10 & 0.69 \\
\hline $\mathrm{G}_{2}$ & 6 & 0.70 & 4.699 & 1.50 & 0.18 \\
\hline $\mathrm{G}_{3}$ & 6 & 0.20 & 4.302 & 1.28 & 0.26 \\
\hline $\mathrm{G}_{4}$ & 6 & 0.28 & 4.173 & 1.06 & 0.11 \\
\hline $\mathrm{G}_{5}$ & 6 & 0.13 & 4.183 & 0.98 & 0.12 \\
\hline $\mathrm{G}_{6}$ & 6 & 0.04 & 4.362 & $2.11^{* *}$ & 0.49 \\
\hline $\mathrm{G}_{7}$ & 6 & 0.14 & 4.294 & 0.65 & 0.07 \\
\hline $\mathrm{G}_{8}$ & 6 & 4.54 & 4.932 & 1.04 & $1.56^{\star}$ \\
\hline $\mathrm{G}_{9}$ & 6 & 0.51 & 4.091 & 0.84 & 0.64 \\
\hline $\mathbf{G}_{10}$ & 6 & 0.08 & 4.665 & $1.76^{\star}$ & 0.44 \\
\hline $\mathrm{G}_{11}$ & 6 & 1.58 & 3.831 & 0.88 & 0.34 \\
\hline $\mathbf{G}_{12}$ & 6 & 0.66 & 3.641 & 0.43 & 0.24 \\
\hline $\mathbf{G}_{13}$ & 6 & 0.46 & 3.815 & 0.57 & 0.44 \\
\hline $\mathrm{G}_{14}$ & 6 & 0.35 & 3.741 & 0.65 & 0.51 \\
\hline $\mathbf{G}_{15}$ & 6 & 0.87 & 4.185 & 1.43 & 0.77 \\
\hline $\mathbf{G}_{16}$ & 6 & 0.26 & 3.864 & 0.70 & 0.43 \\
\hline $\mathrm{G}_{17}$ & 6 & 0.46 & 3.283 & 0.67 & 0.02 \\
\hline $\mathbf{G}_{18}$ & 6 & 0.53 & 4.468 & 0.50 & 0.19 \\
\hline $\mathrm{G}_{19}$ & 6 & 0.79 & 3.334 & 1.06 & 0.25 \\
\hline $\mathrm{G}_{20}$ & 6 & 0.45 & 3.351 & 0.62 & 0.08 \\
\hline $\mathbf{G}_{21}$ & 6 & 0.04 & 3.633 & 0.91 & 0.27 \\
\hline Bronco & 6 & 0.28 & 4.702 & 1.13 & 0.85 \\
\hline Paulista & 6 & 0.21 & 4.678 & 0.87 & 0.27 \\
\hline Samantha & 6 & 0.27 & 3.681 & 1.06 & 0.02 \\
\hline Xera & 6 & 0.10 & 4.574 & 1.21 & $4.52^{* *}$ \\
\hline Pooled Error & 400 & 19.06 & & & \\
\hline Mean & & & 4.124 & & \\
\hline L.S.D.5\% & & & 0.746 & & \\
\hline
\end{tabular}

response within a target environment (Lin and Binns 1988). The genotypes with the lowest insignificant deviation from regression are most phenotypically stable and vice versa. According to Eberhartand Russell (1966), genotypes with "b" value less than 1.0 and higher $S^{2}$ than zero are said to be specifically adapted to poor or unfavorable environments, while, genotypes having high "b" value are specifically adapted to favorable or high yielding environments. The obtained results in Table
(11) indicated that values of deviation from regression $\left(S^{2}\right.$ ) were non-significant in most used genotypes, indicating the stability of these genotypes regarding this trait. Some genotypes exhibited wide adaptation, while others showed specific adaptation either to favorable or unfavorable environments. Results indicated that the high yielding lines of $G_{1}, G_{2}, G_{18}, G_{3}$ and $G_{7}$ produced high mean yields $(4.765,4.699,4.468,4.302$ and 4.294 tons/feddan., respectively) over all environments, 
had regression coefficient (b) close to unity and deviation from regression $\left(S^{2}{ }_{d}\right)$ not significantly from zero. These results indicated its high yielding performance based on wide adaptation and stability of performance over all environments.

The lines of $G_{1}, G_{2}, G_{3}$ and $G_{10}$ as well as the check cultivar Bronco produced high yield over range of environments, showed high regression coefficient $\left(b_{i}>1\right)$ and non-significant deviation from regression $\left(S_{d}^{2}\right)$, indicated specific adaptability of these genotypes to favorable or high yielding environments. It indicated that these lines could produce high yield at favorable environments with fertile soil, adequate water and other inputs. On the contrary, the lines $\mathrm{G}_{7}$ and $\mathrm{G}_{18}$ as well as the check cultivar Paulista showed low regression coefficient $\left(b_{i}<1\right)$ and non-significant deviation from regression $\left(S_{d}^{2}\right)$, indicated specific adaptability of these genotypes to unfavorable environments. It is evident that these genotypes could be used as stress tolerant genotypes under stressed environments (poor yielding or unfavorable environments).

\section{REFERENCES}

A.O.A.C. 1990. Association of Official Analytical Chemistries, $15^{\text {th }}$ ed. Washington. D. C., USA.

Carbonell S.A.M., Filho J.A.A., Dias L.A.S., Garcia A.A.F. and Morais L.K. 2004. Common bean cultivars and lines interactions with environments. Sci. Agric. 61(2), 169-177.

Comstock R.E. and Moll R.H. 1963. Genotype $\times$ environment interaction. Statistical genetics and plant breeding NAS-NRG-Publ. 982, 174196.

Eberhart S.A. and Russell W.A. 1966. Stability parameters for comparing varieties. Crop Sci. 6, 36-40.

Elhag A.Z. and Hussein A.M. 2014. Effects of sowing date and plant population on snap bean (Phaseolus vulgaris I.) growth and pod yield in Khartoum State. Universal J. Agric. Res. 2(3), 115-118.

Esmaeilzadeh S. and Aminpanah H. 2015. Effects of planting date and spatial arrangement on common bean (phaseolus vulgaris) yield under weed-free and weedy conditions. Planta Daninha 33(3), 425-432.

Finlay K.W. and Wilkinson G.N. 1963. The analysis of adaptation in a plant breeding programme. Aust. J. Agric. Res. 14, 742-754.

Getachew E.A. and Tesfaye A. 2015. Impact of sowing date and plant spacing on yield, quality and disease incidence of snap bean (Phaseolus vulgaris I.) varieties at Jimma
Southwestern, Ethiopia. Global Advanced Res. J. Educational Res. and Review 4(5), 081-089.

Getachew E., Tesfaye A. and Mulualem T. 2014a. The effects of sowing date and spacing for yield of green bean (Phaseolus vulgaris L.) varieties at Jimma, Southwestern Ethiopia. Sky J. Agric. Res. 3(9), 174-180.

Getachew E., Mohammed A., Tesfaye A. and Nebiyu A. 2014b. Growth and yield response of green beans (Phaseolus vulgaris L.) In relation to time of sowing and plant spacing in the humid tropics of Jimma, southwest Ethiopia. Int. J. Soil. Crop Sci. 2(5), 61-67.

Hamed A.A. and Naglaa A.S. Muhanna 2017. Breeding for rust resistance and some economic characters in snap bean. Egypt. J. Plant Breed., 21(2), 339-361.

Hamed A.A., Muhanna N.A.S. and Abd Rabou A.M. 2012. Screening and inheritance of rust resistance in snap bean. Egypt. J. Plant Breed., 16(1), 99-113.

Hussein A.H. and Abd El-Hady M.A.H. 2015. A comparison of some promising lines and commercial cultivars of cowpea. Egypt. J. Plant Breed. 19(1), 101-109.

Khalifa G.E., Eljack A.E., Mohammed M.I., Elamin O.M. and Mohamed E.S. 2013. Yield stability in common bean genotypes (Phaseolus vulgaris L.) in the Sudan. J. Plant Breed. Crop Sci. 5(10), 203-220.

Khereba A.H., Abdel-Ati K.E.A., Faris F.S. and Hamed A.A. 2000. Genetic studies on bean (Phaseolus vulgaris L.) 1. Mode of inheritance of number of days to flowering, green yield and some pod characteristics. Egypt. J. Plant Breed., 4, 137-156.

Mounir A.M., Abo El-Yazid A., Orabi I.O.A., Zahran A.A. and El-Oksh I.I. 2015. Effect of sowing date, gamma irradiation and intercultivar differences on growth, pod characteristics and some endogenous plant growth regulators in snap beans. World J. Agric, Sci. 11(6), 380390.

Pereira H.S., Bueno L.G., Peloso M.J.D., Abreu A.F.B., Moreira J.A.A., Martins M., Wendland A., Faria L.C., Souza T.L.P.O. and Melo L.C. 2014. Agronomic performance and stability of andean common bean lines with white grains in Brazil. Bragantia and Campinas 73(2), 130137.

Seyum E.G. 2014. Influence of plant spacing and date of sowing on yield and yield components of two snap bean (Phaseolus vulgaris L.) varie- 

economic characters in snap bean

ties in Jimma, Southwestern Ethiopia. Merit Res. J. Agric. Sci. Soil Sci. 2(7), 86-95.

Snedecor G.W. and Cochran W.G. 1967. Statistical Methods. $7^{\text {th }}$ Edition, lowa State Univ. Press, Ames, lowa, U.S.A.

Stavely J.R., Steadman J.R. and McMillan R.T. 1989. New pathogenic variability in Uromyces appendiculatus in the North America. Plant Dis., 73, 428-432.

Swegarden H.R., Sheaffer C.C. and Michaels T.E. 2016. Yield stability of heirloom dry bean
(Phaseolus vulgaris L.) cultivars in midwest organic production. HortScience 51(1), 8-14.

Tadesse T., Tekalign A., Mulugeta B. and Sefera G. 2017. Identification of stability and adaptability of small red bean cultivars using AMMI analysis. Plant 5(6), 99-103.

Yoldas, F. and Esiyok D. 2007. Effects of sowing dates and cultural treatments on growth, quality and yield of processing beans. Pakistan J. Biological Sci. 10, 2470-2474. 


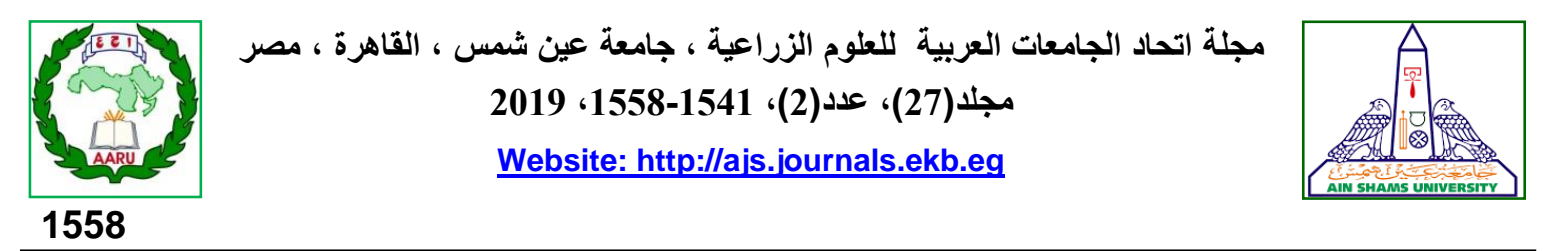

التفاعل بين الطرز الوراثية والبيئة وتحليل الثبات الوراثى لبعض الصفات الاقتصادية فى الفى الفاصوليا الخضراء

[127]

هبة زين العابدين إبراهيم1" - محمد امام رجب2 - نورا محمد طه2 - - انتصار مصطفى اسماعيل أبوحمده1

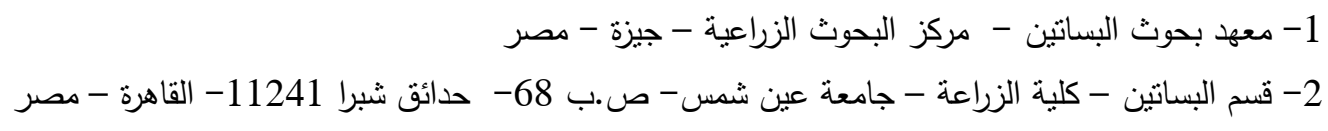

${ }^{*}$ Corresponding author: hebazain83@gamil.com

Received 13 April, $2019 \quad$ Accepted 17 April, 2019

يؤثر على هذه الصفات. وكان التفاعل بين التزاكيب

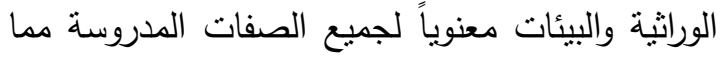
يدل على أن آداء التركيب الوراثى يختلف اختلافا كبيرا

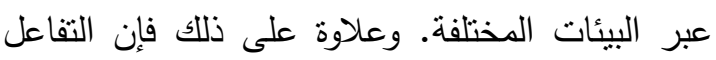
بين التراكيب الوراثية والبيئات (دالة خطية) كان معنوياً

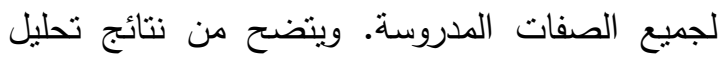

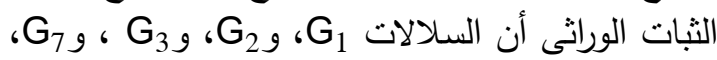

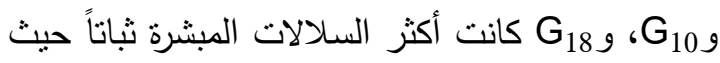

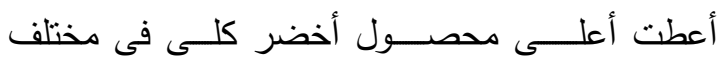
البيئات، كما كانت متأقلمة مع البيئة لصفة المحصول.

الكلمات الدالة: الفاصوليا الخضراء، التراكيب الوراثية، الثبات

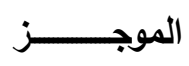

أجريت هذه الدراسة بهدف نقييم إحدى وعشرون سلالة جديده مبشره من الفاصوليا الخضراء ومقارنتها

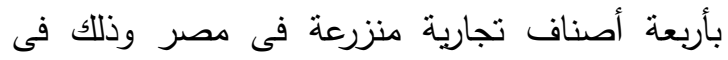
أربعة مواعيد للزراعة فى موسمين متناليتين في الفترة فئرية

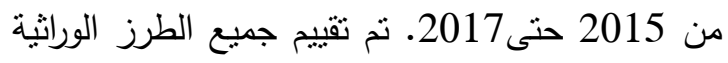

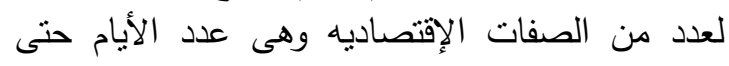
التزهير، وطول القرن، وقطر القرن، ومحتوى القرون الأنيا

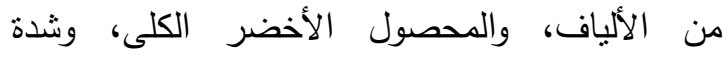
الإصابة بالصدأ. وأثنارت النتائج إلى أن الثلى الثفاعل

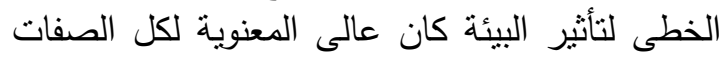
الدروسة مؤكدا وجود فروق بين البيئات المختلفة مما ليات الئان 